\title{
Detection of SARS-COV-2 receptor ACE-2 mRNA in thyroid cells: a clue for COVID-19-related subacute thyroiditis
}

\author{
M. Rotondi ${ }^{1,2} \cdot$ F. Coperchini ${ }^{1}$ - G. Ricci ${ }^{1} \cdot$ M. Denegri ${ }^{3} \cdot$ L. Croce $^{1,2} \cdot$ S. T. Ngnitejeu ${ }^{4} \cdot$ L. Villani $^{5} \cdot$ F. Magri $^{1,2} \cdot$ F. Latrofa $^{6}$. \\ L. Chiovato ${ }^{1,2}$
}

Received: 2 September 2020 / Accepted: 25 September 2020 / Published online: 6 October 2020

(c) The Author(s) 2020

\begin{abstract}
Purpose SARS-COV-2 is a pathogenic agent belonging to the coronavirus family, responsible for the current global world pandemic. Angiotensin-converting enzyme 2 (ACE-2) is the receptor for cellular entry of SARS-CoV-2. ACE-2 is a type I transmembrane metallo-carboxypeptidase involved in the Renin-Angiotensin pathway. By analyzing two independent databases, ACE-2 was identified in several human tissues including the thyroid. Although some cases of COVID-19-related subacute thyroiditis were recently described, direct proof for the expression of the ACE-2 mRNA in thyroid cells is still lacking. Aim of the present study was to investigate by RT-PCR whether the mRNA encoding for ACE-2 is present in human thyroid cells.

Methods RT-PCR was performed on in vitro ex vivo study on thyroid tissue samples (15 patients undergoing thyroidectomy for benign thyroid nodules) and primary thyroid cell cultures.

Results The ACE-2 mRNA was detected in all surgical thyroid tissue samples $(n=15)$. Compared with two reporter genes (GAPDH: $0.052 \pm 0.0026 \mathrm{Cycles}^{-1}$; $\beta$-actin: $0.044 \pm 0.0025 \mathrm{Cycles}^{-1}$; ACE-2: $0.035 \pm 0.0024 \mathrm{Cycles}^{-1}$ ), the mean level of transcript expression for ACE-2 mRNA was abundant. The expression of ACE-2 mRNA in follicular cells was confirmed by analyzing primary cultures of thyroid cells, which expressed the ACE-2 mRNA at levels similar to tissues.

Conclusions The results of the present study demonstrate that the mRNA encoding for the ACE-2 receptor is expressed in thyroid follicular cells, making them a potential target for SARS-COV-2 entry. Future clinical studies in patients with COVID-19 will be required for increase our understanding of the thyroid repercussions of SARS-CoV-2 infection.
\end{abstract}

Keywords Thyroid $\cdot$ Thyrocytes $\cdot$ SARS-COV-2 $\cdot$ COVID-19 $\cdot$ ACE-2

L. Chiovato

luca.chiovato@icsmaugeri.it

1 Laboratory for Endocrine Disruptors, Unit of Internal Medicine and Endocrinology, Istituti Clinici Scientifici Maugeri IRCCS, 27100 Pavia, PV, Italy

2 Department of Internal Medicine and Therapeutics, University of Pavia, Via S. Maugeri 4, 27100 Pavia, PV, Italy

3 Unit of Molecular Cardiology, Istituti Clinici Scientifici Maugeri IRCCS, 27100 Pavia, Italy

4 Department of General and Minimally Invasive Surgery, Istituti Clinici Scientifici Maugeri IRCCS, 27100 Pavia, PV, Italy

5 Unit of Pathology, Istituti Clinici Scientifici Maugeri IRCCS, 27100 Pavia, PV, Italy

6 Department of Clinical and Experimental Medicine, University of Pisa, 56124 Pisa, PI, Italy

\section{Introduction}

SARS-COV-2 is a pathogenic agent, belonging to the coronavirus family, responsible for the current global world pandemic [1]. The clinical picture of COVID-19 disease is in part similar to that previously reported for other coronavirus infections (i.e. SARS and MERS) [2]. In particular, pneumonia-associated symptoms, acute respiratory distress syndrome (ARDS), sepsis and multiple organ failure [3-6] are peculiar manifestations of severe COVID-19 disease. Unfortunately, at present there are no approved therapies for the treatment of COVID-19. Thus, scientists are making a great effort to elucidate SARSCOV-2 to develop possible effective therapeutic strategies while waiting for the development of a vaccine. In this context, great interest stemmed from the demonstration of a cell membrane receptor through which SARS-COV-2 
would enter cells of the host tissue. Several studies suggest that SARS-COV-2, similarly to SARS-COV and NL63/ HCoV-NL63, utilizes the Angiotensin-converting enzyme 2 (ACE-2) as a cellular entry receptor [7]. ACE-2 is a type I transmembrane metallo-carboxypeptidase which, being involved in the Renin-Angiotensin pathway, is targeted for the treatment of hypertension [8]. ACE-2 maps to chromosome Xp22, spans $39.98 \mathrm{~kb}$ of genomic DNA, and contains 20 introns and 18 exons [9]. ACE- 2 is mainly located in extracellular regions (cell membrane) or secreted. It is known to be expressed in a variety of different tissues: in the upper and lower human respiratory tract, in the myocardium and in the gastrointestinal mucosa $[7,10]$, all tissues shown to harbour SARSCOV-2 [10-12]. Hoffman et al., by using several cell lines, demonstrated that the SARS-CoV-2 infection depends on the presence of host cell receptor ACE-2 [13]. In addition, by using a monkey cell line suitable for SARS-CoV-2 replication, Zhou et al. found that treatment with an antiACE- 2 antibody prevented the cell entry of SARS-COV-2 $[14,15]$. Based on these findings, and on the evidence that ACE-2 is expressed by several tissues, it was hypothesized that SARS-COV-2 would infect not only the respiratory tract cells, a main target of COVID-19 disease, but also other tissue cells expressing ACE-2.

The possibility that SARS-CoV-2 could also infect thyroid cells derives from the notion that different viruslike particles are detectable in the follicular epithelium of patients with subacute thyroiditis (SAT) [16] and, most recently, by some independent case reports of SAT related to SARS-CoV-2 [17-22]. The anatomic location of the thyroid, which is contiguous to the upper airways, a main entrance site of corona viruses, further supports the hypothesis that the thyroid could be a target of SARS-CoV-2. As a matter of fact, it was previously reported that a substantial number of patients with Severe Acute Respiratory Syndrome (SARS-CoV) displayed thyroid function abnormalities and disruption of the follicular architecture [23]. From a clinical point of view, the fact that some COVID-19 patients complain of ear pain (i.e. a classical symptom of SAT) would further support the hypothesis that SARS$\mathrm{CoV}-2$ could infect the thyroid, thus producing a subacute inflammation. Eventually, this pathologic process could be clinically relevant because SAT-related thyrotoxicosis could contribute to the cardiovascular complications observed in COVID-19 patients. In line with this view, Li et al., by analyzing two independent databases, identified the presence of ACE-2 in several human tissues including the thyroid [24]. However, direct proof for the existence of the ACE-2 mRNA in thyroid cells is still lacking. Aim of the present study was to investigate by RT-PCR whether the mRNA encoding for ACE- 2 is expressed by thyroid tissue samples and in primary cultures of thyroid cells.

\section{Materials and methods}

\section{Thyroid tissue samples}

Surgical samples of fifteen thyroids were obtained from the disease-free tissue of patients who underwent thyroidectomy for a nodular goiter (12 women and 3 men). All specimens used in the study were snap frozen at surgery and then maintained at $-80^{\circ} \mathrm{C}$. Written informed consent for the study was obtained from all patients.

\section{Primary cultures of human thyroid cells}

To confirm that the amplified genes specifically belonged to follicular thyroid cells, two primary cultures of normal thyrocytes were also investigated. Briefly, surgical specimens of normal human thyroid were obtained from the contralateral disease-free lobe of patients who underwent thyroidectomy for a solitary malignant nodule $(n=2)$. Surgical specimens were minced and then incubated with collagenase type II (Sigma, Saint Louis, MO, USA) $5 \mathrm{mg} /$ $\mathrm{ml}$, in $5 \mathrm{ml}$ of Coon's $\mathrm{F} 12$ medium, for $4 \mathrm{~h}$ at $37{ }^{\circ} \mathrm{C}$. Then, $10 \mathrm{ml}$ of Coon's F12 medium were added, following which, cells were filtered, spun at $1000 \times \mathrm{g}$ for $10 \mathrm{~min}$, washed with Coon's F12 medium, spun again, and finally re-suspended in complete medium containing 5\% newborn calf serum and a mixture of six hormones including insulin $(5 \mu \mathrm{g} /$ $\mathrm{ml})$, hydrocortisone $(50 \mu \mathrm{g} / \mathrm{ml})$, transferrin $(5 \mu \mathrm{g} / \mathrm{ml})$, somatostatin $(10 \mathrm{ng} / \mathrm{ml})$, gly-his-lysine $(10 \mathrm{ng} / \mathrm{ml})$ and bovine TSH $(1 \mathrm{mU} / \mathrm{ml})$.

\section{Real-time PCR}

Total RNA was isolated from thyroid specimens using a Total RNA purification kit according to the manufacturer's instructions (Norgen Biotek, Canada). Genomic DNA was digested using the DNAse enzyme (Norgen Biotek, Canada) at room temperature for $15 \mathrm{~min}$ and following the manufacturer's protocol. Total RNA from samples was reverse transcribed into cDNA using a Sensi Fast c-DNA synthesis kit (Bioline, London, UK), following the manufacturer's instructions. Real-time PCR was performed using Sensi-Fast SYBR Green Hi-ROX kit (Bioline, London, UK) on a StepOne Plus Applied Biosystems real-time PCR system. Amplification was done under the following conditions: $95^{\circ} \mathrm{C}$ for $2 \mathrm{~min}$; followed by 40 cycles of $95^{\circ} \mathrm{C}$, $5 \mathrm{~s}$ and $60^{\circ} \mathrm{C}, 10 \mathrm{~s}$. $\beta$-actin and GAPDH were used as endogenous controls. Pre-designed primers targeting human ACE-2 (F: GGGATCAGAGATCGGAAGAAGAAA; R: AGGAGGTCTGAACATCATCAGTG) GAPDH (F: AAA TCCCATCACCATCTTCC; R: GGTTCACACCCATGA 
CGAAC) and $\beta$-actin (F: TGCGTGACATGAGAAG; R: GCTCGTAGCTTCTCCA) were obtained from Biomers. net GMBH (Soflinger, Germany). Primers of ACE-2 were chosen based on the study by Ma et al. [25]. All samples were run in triplicate. The means of the number of $\mathrm{Cycles}^{-1}$ of ACE-2, GAPDH and $\beta$-actin genes were compared in all samples. Moreover, the expression of ACE2 in relation to both GAPDH and $\beta$-actin was calculated for all the samples.

\section{Results}

\section{Expression of ACE-2 mRNA in thyroid tissue specimens}

The expression levels of ACE- 2 mRNA were evaluated in 15 different thyroid tissue specimens and in two primary thyroid cells cultures. The ACE-2 mRNA was detected in all thyroid tissue samples. The mean level of transcript expression for ACE-2 mRNA was calculated and compared with that of GAPDH and of $\beta$-actin (two reporter genes ubiquitously expressed by cells). As shown in Fig. 1, large amounts of ACE-2 mRNA were detected (GAPDH: $0.052 \pm 0.0026 \mathrm{Cycles}^{-1} ; \beta$-actin. $0.044 \pm 0.0025 \mathrm{Cycles}^{-1}$; ACE-2: $0.035 \pm 0.0024 \mathrm{Cycles}^{-1}$ ).

To confirm the expression of ACE- 2 mRNA by follicular cells, primary cultures of thyroid cells were also evaluated (Fig. 2). Interestingly, the expression levels of ACE-2 mRNA were superimposable between thyroid tissue specimens and follicular thyroid cells in primary culture (Figs. 1,2). These findings would indicate that the total RNA isolated and reverse transcribed into cDNA from tissues derived rather exclusively from follicular thyroid cells. Moreover, the ACE-2/GAPDH mRNAs ratio, related to $\beta$-actin,

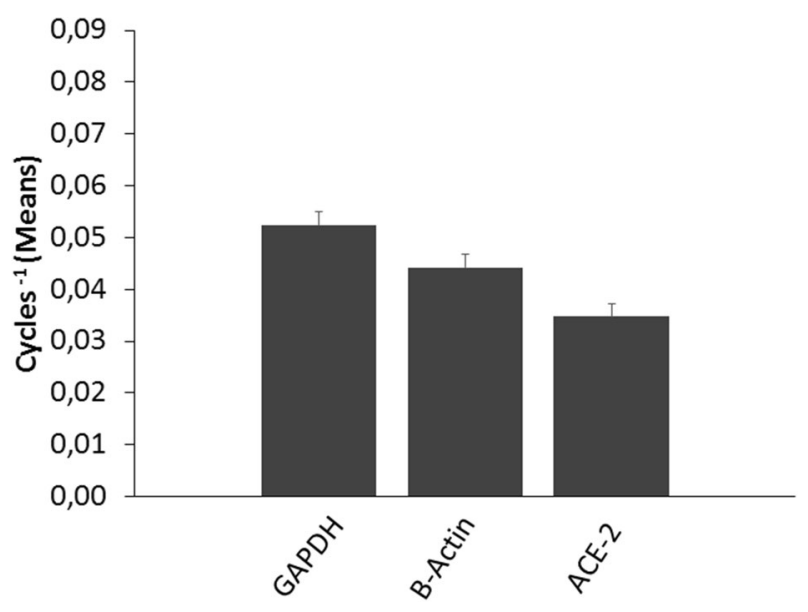

Fig. 1 Mean expression of ACE-2 in thyroid tissue specimens. The expression of GAPDH, $\beta$-actin and ACE- 2 are shown as means of Cycles $^{-1}$

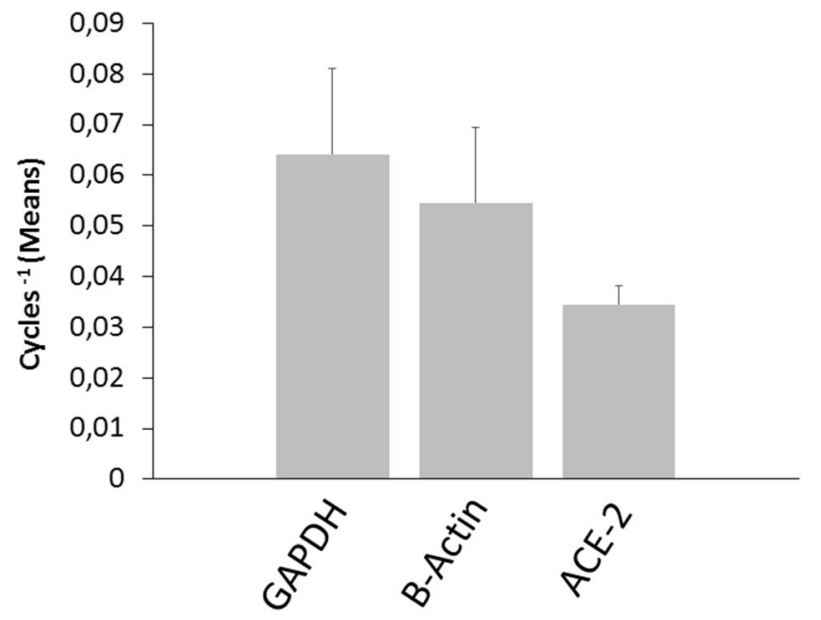

Fig. 2 Mean expression of ACE-2 in primary cultures of thyroid cells. The expression of GAPDH, $\beta$-actin and ACE- 2 are shown as means of Cycles ${ }^{-1}$

revealed no substantial differences among the 15 thyroid tissue samples (Fig. 3a). The same result was found when the ACE-2/ $\beta$-actin ratio was calculated as percentage of GAPDH (Fig. 3b). Taken together the above results clearly indicate an overall between-patients homogeneity for the expression levels of the mRNA encoding for the ACE-2 gene.

\section{Discussion}

The present study provides the first demonstration that the mRNA of the SARS-COV-2 receptor, ACE-2 is expressed in thyroid cells. In addition, by comparing the expression levels of ACE-2 mRNA with those of two reporter genes (GAPDH and $\beta$-actin), it was observed that the ACE-2 mRNA is abundantly expressed by thyroid cells.

Several studies highlighted that SARS-COV-2 enters the host cells through ACE- 2 receptor, a mandatory step for viral replication and transmission [13, 26, 27]. Based on these findings, the expression pattern of ACE-2 mRNA in specific cell types could identify further routes of SARS-CoV-2 infection in humans. Recent studies have shown that SARS-CoV-2 infection not only affects the upper respiratory tract cells, but also involves other organs. Indeed, SARS-CoV-2 was detected in a variety of human tissues belonging to the respiratory, cardiovascular, digestive, urinary and reproductive systems [28, 29]. ACE2 mRNA was found to be expressed in spermatogonia, as well as Leydig and Sertoli cells, thus suggesting that testis may be potentially vulnerable to SARS-CoV-2 infection. Similarly, Jing et al. suggested that SARS-Cov-2 may infect the ovary, uterus, vagina and placenta through the ubiquitous expression of the ACE-2 receptor [30]. ACE-2 

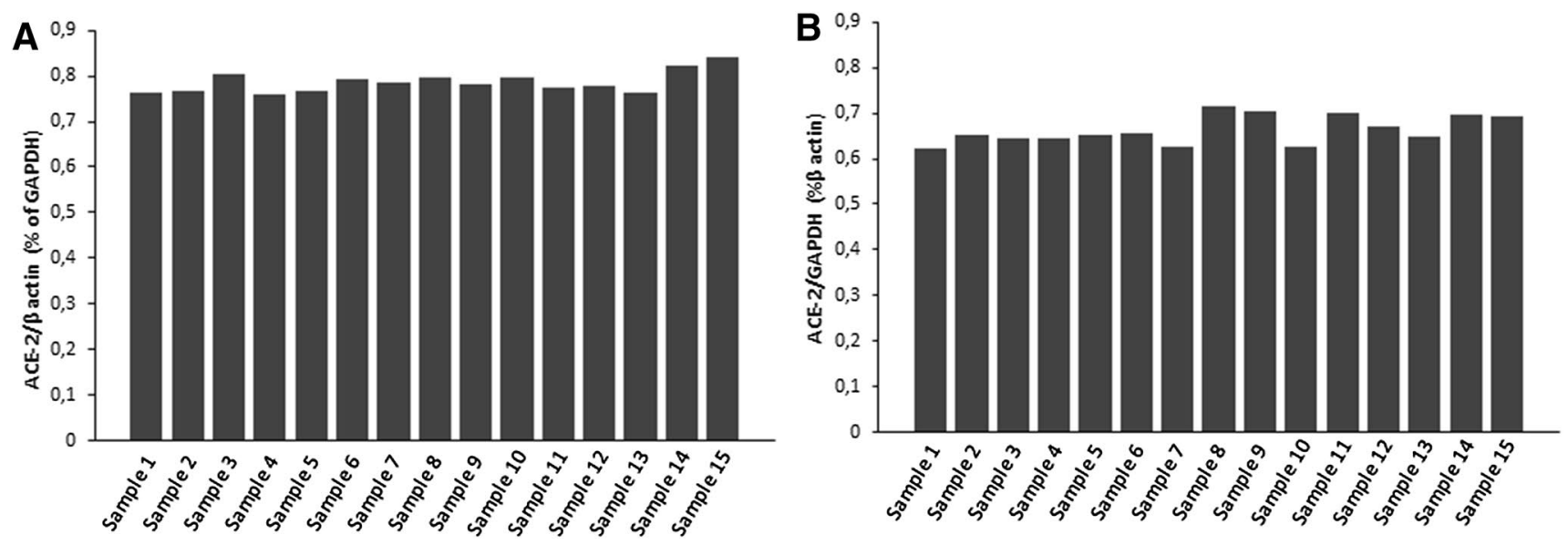

Fig. 3 Panel a ACE-2/ $\beta$-actin ratio calculated as percentage of GAPDH. Bars are representative of distinct thyroid tissue specimens. Panel b ACE-2/ GAPDH ratio calculated as percentage of $\beta$-actin. Bars are representative of distinct thyroid tissue specimens

expression was also demonstrated in endothelial cells from arterial and venous vessels [31]. More importantly, there is clear-cut evidence that endothelial cells are prone to acquire SARS-CoV-2 infection [32], with subsequent development of endotheliitis, endothelial cell damage, systemic vasculitis and disseminated intravascular coagulation.

To provide evidence on whether the thyroid might be a target organ of SARS-COV-2 infection, the present study aimed at identifying ACE-2 in thyroid cells. RT-PCR analysis showed that the ACE-2 mRNA is expressed at consistent levels in thyroid tissue specimens and cells. These findings are in line with data from previous in silico studies. The detection of the mRNA encoding for ACE-2 in thyroid tissue is for sure a relevant finding. However, immunohistochemical studies will be required to confirm that the ACE-2 protein is present on thyroid cells. The expression level of the ACE-2 mRNA in the thyroid were not compared with that in other organs. However, previous data [33] suggest that expression level of the ACE-2 mRNA in the thyroid, even if relevant, is lower than that in lung, small intestine and colon, and higher than that in breast, liver and skeletal muscle. Further studies, specifically designed to compare the relative expression of the ACE-2 mRNA in different human tissues, will be needed to further clarify this issue.

Taken together, the above described data support the view that the presence of the viral receptor correlates with the susceptibility to SARS-CoV-2 infection and that the receptor expression in tissues other than the lung may explain the multi-organ failure observed in severe cases [34]. As far as the thyroid gland is concerned, $\mathrm{Li}$ et al. first reported the expression of ACE-2 in the thyroid, but this was done only by in silico prediction analysis [24]. Our results demonstrate for the first time the expression of ACE2 mRNA in human thyroid surgical specimens and in primary cultures of thyroid cells. It should also be highlighted that, by comparing the expression of ACE- 2 mRNA with two different transcripts such as GAPDH and $\beta$-actin, the ACE- 2 mRNA was found to be abundant and, more importantly, homogenously expressed by thyroid cells.

It is important to note that, as recently demonstrated, SARS-CoV-2 infection requires the ACE- 2 receptor to coexist with type II serine protease trans-membranes (TMPRSS2) [25]. TMPRSS2 expression was not evaluated in the present study. However, as recently reviewed by Lazartigues et al., in silico studies indicate that thyroid tissues, with no gender difference, exhibit a high expression of the TMPRSS2 mRNA [35].

The results of the present study suggest that the thyroid might be vulnerable to SARS-CoV-2 infection. This would fit with the recent clinical descriptions of COVID-19related SAT [17-20]. It is interesting to remember that thyroid repercussions were also described during the 2002 outbreak of SARS-CoV [17, 23]. The expression of ACE-2 was related to the SARS coronavirus aggression in other endocrine glands. In particular, Yang et al. [36] reported that ACE-2 is expressed in the endocrine pancreas, which, after being infected by the SARS coronavirus, undergoes islet damage and impaired insulin release. More recently, Liu et al. [37] showed that some patients with COVID19 disease experience pancreatic injury leading to insulin deficiency.

In conclusion, the results of the present study clearly indicate that the mRNA encoding for the ACE-2 receptor is expressed in follicular thyroid cells, making them a potential target for SARS-COV-2 entry. Future clinical studies in patients with COVID-19 will be required to improve our 
understanding of the thyroid repercussions of SARS-CoV-2 infection.

Funding Open access funding provided by Università degli Studi di Pavia within the CRUI-CARE Agreement. This paper was not supported by any grant or funding.

\section{Compliance with ethical standards}

Conflict of interest The authors have nothing to disclose.

Research involving human participants and/or animals All procedures performed in studies involving human participants were in accordance with the ethical standards of the institutional and/or national research committee and with the 1964 Helsinki declaration and its later amendments or comparable ethical standards.

Informed consent Written informed consent for the study was obtained from all patients.

Open Access This article is licensed under a Creative Commons Attribution 4.0 International License, which permits use, sharing, adaptation, distribution and reproduction in any medium or format, as long as you give appropriate credit to the original author(s) and the source, provide a link to the Creative Commons licence, and indicate if changes were made. The images or other third party material in this article are included in the article's Creative Commons licence, unless indicated otherwise in a credit line to the material. If material is not included in the article's Creative Commons licence and your intended use is not permitted by statutory regulation or exceeds the permitted use, you will need to obtain permission directly from the copyright holder. To view a copy of this licence, visit http://creativecommons .org/licenses/by/4.0/.

\section{References}

1. Huang C, Wang Y, Li X et al (2020) Clinical features of patients infected with 2019 novel coronavirus in Wuhan, China. Lancet 395(10223):497-506. https://doi.org/10.1016/s0140 -6736(20)30183-5

2. Andersen KG, Rambaut A, Lipkin WI, Holmes EC, Garry RF (2020) The proximal origin of SARS-CoV-2. Nat Med 26(4):450 452. https://doi.org/10.1038/s41591-020-0820-9

3. Mehta P, Mcauley DF, Brown M et al (2020) COVID-19: consider cytokine storm syndromes and immunosuppression. Lancet 395(10229):1033-1034. https://doi.org/10.1016/s0140 $-6736(20) 30628-0$

4. Moore JB, June CH (2020) Cytokine release syndrome in severe COVID-19. Science 368(6490):473-474. https://doi.org/10.1126/ science.abb8925

5. Coperchini F, Chiovato L, Croce L, Magri F, Rotondi M (2020) The cytokine storm in COVID-19: an overview of the involvement of the chemokine/chemokine-receptor system. Cytokine Growth Factor Rev. https://doi.org/10.1016/j.cytogfr.2020.05.003

6. Oliviero A, De Castro F, Coperchini F, Chiovato L, Rotondi M (2020) COVID-19 pulmonary and olfactory dysfunctions: is the chemokine CXCL10 the common denominator? Neuroscientist. https://doi.org/10.1177/1073858420939033
7. Li W, Moore MJ, Vasilieva $\mathrm{N}$ et al (2003) Angiotensin-converting enzyme 2 is a functional receptor for the SARS coronavirus. Nature 426(6965):450-454. https://doi.org/10.1038/nature02145

8. Riordan JF (2003) Angiotensin-I-converting enzyme and its relatives. Genome Biol 4(8):225. https://doi.org/10.1186/ gb-2003-4-8-225

9. Turner AJ, Tipnis SR, Guy JI, Rice G, Hooper NM (2002) ACEH/ ACE2 is a novel mammalian metallocarboxypeptidase and a homologue of angiotensin-converting enzyme insensitive to ace inhibitors. Can J Physiol Pharmacol 80(4):346-353. https://doi. org/10.1139/y02-021

10. Harmer D, Gilbert M, Borman R, Clark KL (2002) Quantitative mRNA expression profiling of ACE 2, a novel homologue of angiotensin converting enzyme. Febs Lett 532(1-2):107-110. https://doi.org/10.1016/s0014-5793(02)03640-2

11. Ksiazek TG, Erdman D, Goldsmith CS et al (2003) A novel coronavirus associated with severe acute respiratory syndrome. N Engl J Med 348(20):1953-1966. https://doi.org/10.1056/nejmo a030781

12. Leung WK, To KF, Chan PK et al (2003) Enteric involvement of severe acute respiratory syndrome-associated coronavirus infection. Gastroenterology 125(4):1011-1017. https://doi. org/10.1016/s0016-5085(03)01215-0

13. Hoffmann M, Kleine-Weber H, Schroeder S et al (2020) SARS$\mathrm{CoV}-2$ cell entry depends on ACE2 and TMPRSS2 and is blocked by a clinically proven protease inhibitor. Cell 181(2):271-280. e278. https://doi.org/10.1016/j.cell.2020.02.052

14. Zhou P, Yang XL, Wang XG et al (2020) A pneumonia outbreak associated with a new coronavirus of probable bat origin. Nature 579(7798):270-273. https://doi.org/10.1038/s41586-020-2012-7

15. Zhou Y, Vedantham P, Lu K et al (2015) Protease inhibitors targeting coronavirus and filovirus entry. Antiviral Res 116:76-84. https://doi.org/10.1016/j.antiviral.2015.01.011

16. Desailloud R, Hober D (2009) Viruses and thyroiditis: an update. Virol J 6:5. https://doi.org/10.1186/1743-422x-6-5

17. Brancatella A, Ricci D, Viola N, Sgrò D, Santini F, Latrofa F (2020) Subacute thyroiditis after SARS-CoV-2 infection. J Clin Endocrinol Metab. https://doi.org/10.1210/clinem/dgaa276

18. Ruggeri RM, Campennì A, Siracusa M, Frazzetto G, Gullo D (2020) Subacute thyroiditis in a patient infected with SARSCoV-2: an endocrine complication linked to the COVID-19 pandemic. Hormones. https://doi.org/10.1007/s42000-020-00230 -W

19. Asfuroglu Kalkan E, Ates I (2020) A case of subacute thyroiditis associated with Covid-19 infection. J Endocrinol Investig 43(8):1173-1174. https://doi.org/10.1007/s40618-020-01316-3

20. Ippolito S, Dentali F, Tanda ML (2020) SARS-CoV-2: a potential trigger for subacute thyroiditis? Insights from a case report. J Endocrinol Investig 43(8):1171-1172. https://doi.org/10.1007/ s40618-020-01312-7

21. Brancatella A, Ricci D, Cappellani D et al (2020) Is subacute thyroiditis an underestimated manifestation of SARS-CoV-2 infection? Insights from a case series. J Clin Endocrinol Metab. https://doi.org/10.1210/clinem/dgaa537

22. Muller I, Cannavaro D, Dazzi D et al (2020) SARS-CoV-2-related atypical thyroiditis. Lancet Diabetes Endocrinol 8(9):739-741. https://doi.org/10.1016/s2213-8587(20)30266-7

23. Wei L, Sun S, Xu CH et al (2007) Pathology of the thyroid in severe acute respiratory syndrome. Hum Pathol 38(1):95-102. https://doi.org/10.1016/j.humpath.2006.06.011

24. My Li, Li L, Zhang Y, Wang XS (2020) Expression of the SARSCoV-2 cell receptor gene ACE2 in a wide variety of human tissues. Infect Dis Poverty 9(1):45. https://doi.org/10.1186/s4024 9-020-00662-X

25. Ma D, Chen CB, Jhanji V et al (2020) Expression of SARS-CoV-2 receptor ACE2 and TMPRSS2 in human primary conjunctival and 
pterygium cell lines and in mouse cornea. Eye 34(7):1212-1219. https://doi.org/10.1038/s41433-020-0939-4

26. Yan R, Zhang Y, Li Y, Xia L, Guo Y, Zhou Q (2020) Structural basis for the recognition of SARS-COV-2 by full-length human ACE2. Science 367(6485):1444-1448. https://doi.org/10.1126/ science.abb2762

27. Wang Q, Zhang Y, Wu L et al (2020) Structural and functional basis of SARS-CoV-2 entry by using human ACE2. Cell 181(4):894-904.e899. https://doi.org/10.1016/j.cell.2020.03.045

28. Zou X, Chen K, Zou J, Han P, Hao J, Han Z (2020) Singlecell RNA-seq data analysis on the receptor ACE2 expression reveals the potential risk of different human organs vulnerable to 2019-nCoV infection. Front Med 14(2):185-192. https://doi. org/10.1007/s11684-020-0754-0

29. Wang Z, Xu X (2020) scRNA-seq profiling of human testes reveals the presence of the ACE2 receptor, a target for SARSCoV-2 infection in spermatogonia, leydig and sertoli cells. Cells. https://doi.org/10.3390/cells9040920

30. Jing Y, Run-Qian L, Hao-Ran W et al (2020) Potential influence of COVID-19/ACE2 on the female reproductive system. Mol Hum Reprod 26(6):367-373. https://doi.org/10.1093/molehr/gaaa030

31. Hamming I, Timens W, Bulthuis ML, Lely AT, Navis G, Van Goor H (2004) Tissue distribution of ACE2 protein, the functional receptor for SARS coronavirus. A first step in understanding SARS pathogenesis. J Pathol 203(2):631-637. https://doi. org/10.1002/path.1570

32. Varga Z, Flammer AJ, Steiger P et al (2020) Endothelial cell infection and endotheliitis in COVID-19. Lancet
395(10234):1417-1418. https://doi.org/10.1016/s0140 $-6736(20) 30937-5$

33. Uhlén M, Fagerberg L, Hallström BM et al (2015) Proteomics. Tissue-based map of the human proteome. Science 347(6220):1260419. https://doi.org/10.1126/science.1260419

34. Devaux CA, Rolain JM, Raoult D (2020) ACE2 receptor polymorphism: susceptibility to SARS-CoV-2, hypertension, multi-organ failure, and COVID-19 disease outcome. J Microbiol Immunol Infect 53(3):425-435. https://doi.org/10.1016/j. jmii.2020.04.015

35. Lazartigues E, Qadir MMF, Mauvais-Jarvis F (2020) Endocrine significance of SARS-CoV-2's reliance on ACE2. Endocrinology. https://doi.org/10.1210/endocr/bqaa108

36. Yang JK, Lin SS, Ji XJ, Guo LM (2010) Binding of SARS coronavirus to its receptor damages islets and causes acute diabetes. Acta Diabetol 47(3):193-199. https://doi.org/10.1007/ s00592-009-0109-4

37. Liu F, Long X, Zhang B, Zhang W, Chen X, Zhang Z (2020) ACE2 expression in pancreas may cause pancreatic damage after SARS-CoV-2 infection. Clin Gastroenterol Hepatol 18(9):21282130.e2122. https://doi.org/10.1016/j.cgh.2020.04.040

Publisher's Note Springer Nature remains neutral with regard to jurisdictional claims in published maps and institutional affiliations. 